\title{
Rural Reconstruction Administration in the Madras State (1963 - 1967 CE)
}

\author{
J. Rajkumar* \\ Assistant Professor of History, Government Arts College (Autonomous), Coimbatore, \\ Tamil Nadu, India; jeyarajrajkumar@gmail.com
}

\begin{abstract}
The object of this study is to survey the facts of rural life in the Madras State during the years 1963 -1967. Rural Reconstruction aims at bringing about an upward change in the whole life of the villager helping him/her to live a better and happier life whole-heartedly. Villages are India's Blood-Vessels. Rural development schemes are people's schemes. As Mahatma rightly remarks, "India lives in villages".
\end{abstract}

Keywords: Co-operatives, Rural Reconstruction, Rural Electrification, Rural Housing, Village

\section{Introduction}

The object of this study is to survey the facts of rural life in the Madras State, as we are inheritors of a rural civilization. Rural Reconstruction is a subject of national importance as the pulse of Indian life beats in the villages of India. The true spirit of India lives in villages and the villages constitute the very heart of India ${ }^{1}$. Rural Life in India is more nearly the whole life in India ${ }^{2}$. Their economy is the foundation of India's economy. In addition to the above, the famine which affected the whole of South India in the nineteenth century devastated the country's village life and its economy completely. The term Rural Reconstruction denotes rebuilding of rural society in all its directions. It was the Great Indian Nobel Laureate, Rabindranath Tagore, who approved the use of the term 'Rural Reconstruction' in one of this letters to Leonard Elmhirst in the twenties ${ }^{3}$ of the last century.

Rural Reconstruction aims at bringing about an upward change in the whole life of the villager helping him/her to live a better and happier life economically, physically, psychologically, socially and spiritually. Villages are India's Blood - vessels. Rural development Schemes are people's schemes. People's full and whole - hearted participation is very much essential. Villages are real India's Life - blood, Life
- nerve. The concept of "Rural Reconstruction" is receiving more attention in the modern era of Globalization. This term needs much clarification. Sixty percent of the population in India lives in villages. Rural Economy is at the very base of Indian Life. As Mahatma, Rightly remarks; "India lives in villages". India breathes through villages. Cottage economy satisfies the physical needs of men for food and drink, clothing and housing ${ }^{4}$.

Mahatma wanted each village to be independent and self - sufficient. In the year Nineteen Sixty three, Madras was one among the most progressive state of the Indian union. It forms the southernmost state of the Indian Union ${ }^{5}$. Thiru M. Bhaktavatsalam was sworn in as Chief- Minister on the afternoon of second October Nineteen Sixty Three. Many outshining schemes are being implemented for Animal-Husbandry department during the year 1963 - 64 Common Era out of which, an intensive egg and poultry production - cum - marketing centre has been introduced ${ }^{6}$ and it is functioning in the sheep farm at Kattupakkam. Furthermore, there are two intensive poultry development blocks is functioning in Thanjavur and Ramanathapuram districts respectively. The Government of Madras took sincere efforts for Defence. The Village Volunteer force was formed in almost all the villages ${ }^{7}$. It made every effort to

${ }^{*}$ Author for correspondence 
impart defence orientation to popular thinking in villages ${ }^{8}$. Due to the outbreak of 1965 War, the government called for a complete shift in the emphasis towards defence efforts during the last four months of Nineteen Sixty Five. In some of the villages, the enthusiasm generated was on a strikingly impressive scale, and it was utilized to implement a variety of community development works. The name and fame of school meals subsidy scheme is becoming popular even in every nook and corner of every village. Madras state continued to lead the rest of India in Rural Electrification'. Co-operative movement has become the order of the day in the life of the rural folk. It brings about a renaissance in the village parts. The achievement touched a new milestone. The total number of co-operative societies which stood at 17,739 at the beginning of the year 1963 increased to 18,637 at the end of the year ${ }^{10}$.

The village co-operatives have altogether brought within their fold 83.8 percent of the population. This shows that everywhere among the rural folk in creating many more co-operative firms. In the field of Panchayat, this state has a tremendous record. Perhaps outshining many states of the Indian Union in this regard. There are Three Hundred and Seventy Four Panchayat Unions and Twelve Thousand and one - hundred and Fourty - eight village panchayat in the state ${ }^{11}$. During the year Nineteen SixtyFive, three key Village Extension centres were started at Pullambadi in Tiruchirappalli, Namagiripet in Salem and Kottaikarankulam in Tirunelveli district and these centres were functioning well ${ }^{12}$. Pre-basic classes were being conducted by the women's welfare organiser for the benefit of the villagers between the age group of two and a half to six. Home service to the women such as helping in preparing home remedies for minor ailments, guide them in proper methods of cooking - thrift and savings and organising group activities. The centre's diversified activities such as to make use of the leisure hours of village women for supplementing their earnings by simple handicrafts. The Women's welfare department works with the integration of voluntary organisations for the welfare of the women and children of the rural areas. The ultimate aim are the upliftment of women and children in Health, Education, Social and Economic improvement, Promotion of thrift and savings by involving them into groups in Madhar sangam, craft centres, Balwadi's.

Under the Rural Industries project programme, there are three project areas in the Madras State. The first one is at Sriperumbudur project in Chingleput district and the second one is at Omalur in Salem district and the last one is at Nanguneri project in Tirunelveli district ${ }^{13}$. At Sriperumbudur, Omalur and Nanguneri, training was imparted for the production of handicraft articles like palmleaf articles, soapstone work and manufacture of scrubbing and floor brushes using palmirah fibre. During the year 1965, one thousand four - hundred and ninety eight rural latrines, six - thousand and nine hundred and one soakage pits and thirty for thousand and one - hundred and thirty - five metres of pucca drains were constructed ${ }^{14}$. The Madras State Government was the pioneer of all the state governments in the field of khadi. It gave enormous amount of gainful employment to millions of under employed and unemployed. Regarding Village housing project, two hundred and thirty - five houses were completed during the year $1965-66^{15}$. During the year 1966, the percentage of villages electrified to the total number of villages is nearly fifty as against the All India average of $9.3^{16}$. The government resigned on sixth march of 1967 after the defeat in the general elections.

\section{Conclusion}

From the above deliberations it is quite clear that the State of Madras reached its zenith in the field of Rural electrification. But in the other aspects such as public health it has functioned satisfactorily. Why because, the government concentrated much on the defence sector as our country witnessed another war. So naturally the importance goes to the safety and security aspects.

\section{References}

1. Kanagaraj A. The light houses of rural reconstruction. Delhi: ISPCK; 2000. p. 1.

2. Krishnaswami SY. Rural problems in Madras: Monograph. Madras: Government Press; 1947. p. 9.

3. Jain NP. Rural reconstruction in India and China: A comparative study. New Delhi: Sterling publishers; 1970. p. 8.

4. Krishnaswami SY. Rural problems in Madras: Monograph. Madras: Government Press; 1947. p. 10.

5. Madras State Administration Report: 1963. Madras: Government Press; 1964. p. 1.

6. Popular Ministries, Schemes, Projects, Historical Events and Visits. Tamilnadu: Tamilnadu Archives; 1981. p. 222.

7. Popular Ministries, Schemes, Projects, Historical Events and Visits. Tamilnadu: Tamilnadu Archives; 1981. p. 220.

8. Madras State Administration Report: 1963. Madras: Government Press; 1964. p. 3.

9. Popular Ministries, Schemes, Projects, Historical events and visits. Tamilnadu: Tamilnadu Archives; 1981. p. 229.

10. Madras State Administration Report: 1963. Madras: Government Press; 1964. p. 4.

11. Madras State Administration Report: 1963. Madras: Government Press; 1964. p. 5. 
12. Madras State Administration Report: 1965. Madras: Government Press; 1966. p. 152.

13. Madras State Administration Report: 1965. Madras: Government Press; 1966. p. 281-2

14. Madras State Administration Report: 1965. Madras: Government Press; 1966. p. 279.

15. Madras State Administration Report: 1965. Madras: Government Press; 1966. p. 226.

16. Popular Ministries, Schemes, Projects, Historical events and visits. Tamilnadu: Tamilnadu Archives; 1981. p. 239.

\section{0ther References}

1. Krishnaswami SY. Rural Problems in Madras: Monograph. Madras: Government Press; 1947.

2. Madras State Administration Report: 1963. Madras: Government Press; 1964.
3. Madras State Administration Report: 1965. Madras: Government Press; 1966.

4. Popular Ministries, Schemes, Projects, Historical events and visits. Tamil Nadu: Tamil Nadu Archives; 1981.

5. Baker CJ. An Indian Rural Economy, 1880-1955: The Tamilnadu Country side. Oxford: OUP; 1985.

6. Jain NP. Rural reconstruction in India and China: A comparative study. New Delhi: Sterling Publishers; 1970.

7. Kanakaraj A. The Light Houses of Rural Reconstruction. Delhi: ISPCK; 2000.

8. Lal PC. Reconstruction and education in rural India. London: George Allen and Unwin Ltd; 1932.

9. Pillay AP. Welfare problems in rural India. Bombay: DB Taraporevala Sons and Co; 1931.

10. Sen S. Rabindranath Tagore on rural reconstruction and community development in India. Calcutta: Visva Bharati; 1943.

11. Sharma OP. Rural Reconstruction in India. Delhi: Anmol Publications; 1987. 